\title{
Investigating Creativity in Computer Science Syllabi in Australia
}

\author{
Anju Thapa \\ School of Computing Technologies \\ RMIT University \\ Melbourne, Australia \\ anju.thapa@rmit.edu.au
}

\author{
Andrew Valentine \\ School of Computing and Information \\ Systems \\ University of Melbourne \\ Melbourne, Australia \\ andrew.valentine@unimelb.edu.au
}

\author{
Margaret Hamilton \\ School of Computing Technologies \\ RMIT University \\ Melbourne, Australia \\ margaret.hamilton@rmit.edu.au
}

\begin{abstract}
Educators, including Computer Science (CS) Educators are aware of the importance of creativity skill in graduates for their employability. Focus has been in building a creative and innovative product to determine the creativity skills. However, educators have ignored the importance of providing a social environment to the students for task motivation which will foster creativity in students. This paper presents the study of the course outlines of 19 universities teaching CS in their undergraduate courses across Australia, focusing on how important task motivation is as one of the main components of creative performance. This research has addressed a document analysis on how creativity, innovation and entrepreneurship have been articulated mostly in the final year of study in CS curriculum. CS educators may need to make sure that creativity is addressed in their courses, thus enhancing creativity skills of CS students. Componential framework of creativity has been addressed. Limitations are discussed.
\end{abstract}

Keywords-creativity, computer science, syllabus, innovation, entrepreneurship

\section{INTRODUCTION}

Creativity is an ignition for great innovation. It is the driving force for all innovations. While creativity used to be associated with art and literature in the past, since the $20^{\text {th }}$ century people have started understanding that novel discovery in science which makes human life easier and solves some problems is creativity [14]. All of the great discoveries of the world started from someone's creative mind and their novel work of turning their idea into reality.

With the growing importance of being creative in innovation, it has been considered as an important soft skill for employment for many years. A report by Parliament of the Commonwealth of Australia in 2017 noted the importance of creativity and innovation in Australia's tertiary education system, thus preparing the workforce for the new economy [6]. Similarly, a report by Deloitte Australia in 2017 suggested creativity as an important soft skill for business success in Australia [7].

During her internship at the Organization for Economic Co-operation and Development (OECD), Yuanyuan Pan presented a report on China's education system and how educational and curriculum reforms are taking place at all levels focusing more on creativity [16]. China is one of the fastest growing countries in terms of its economy. For more economical advances it needs to work on new innovation and entrepreneurial discovery, and the cognitive process which leads to innovation and entrepreneurship is creativity. Hence for the organizational context of entrepreneurship, countries like China are focusing on enhancing creativity skills of students at all levels [22]. If we are looking for a more global perspective, the World Economic Forum report in 2020, discussed creativity as an emerging skill required globally for many countries listed [30]. Another report in the World Economic Forum identified ten skills needed to thrive in the fourth industrial revolution and placed creativity as the third highest skill required in 2020 [11].

These reports emphasize the importance of creativity and the need of creativity in an individual to stand out in the competitive economic world created by industry. With the introduction of creativity in courses and course outlines, one aim is to promote a creative environmental influence on students. While the importance of socio-environment factors is known, far less importance has been placed on innovation [2], however, for innovation, a creative idea is required. How a creative idea can lead to creating new products has been studied in numerous papers where the focus has been on creative individual and creative product. However the environment and task motivation factors which lead to the creative innovation tend to be ignored [2]. Creativity is an important skill sought by ICT employers; hence it is crucial that we include some activities in our course work and provide a task motivation environment which can enhance the creativity skill of ICT students.

\section{BACKGROUND}

The significance of creativity as an essential individual skill has increased in the recent years. It is essential that we foster creativity in our graduates during their university education which leads to great innovations, employability, and new discoveries. In order to motivate students to be creative, it is important that we articulate creativity in our course outlines so that students are aware of course expectations by providing them the social environment and motivation for thinking creatively. The differences in perception between educators and students might exist, where educators may presume that they are providing a creative environment for the students, however students are not aware of such an environment. A study on instructors' and students' perceptions on barriers to creativity education revealed the instructors presume that they are fostering creativity and providing a creative environment for their students, however students feel they lack the element of creativity in their educational experience [12]. Had creativity been articulated and explicitly outlined in the course, students would have the motivation and social environment to foster their creativity skill in the course. 
The importance of creativity is known to educators and hence there has been several methods they have used to foster creativity and several instruments used for measuring creativity.

\section{A. Common instruments used for measuring creativity}

A systematic literature review of creativity in Computer Science (CS) curriculum was conducted with 26 records identified through Institute of Electrical and Electronics Engineers (IEEE) and Association for Computing Machinery (ACM) databases [26]. These papers were studied to find out about the instruments used in measuring creativity and common methods used by CS Educators in their courses.

According to the study, it was found that the common instruments used for measuring creativity are the Torrance Test of Creativity Thinking (TTCT) [24] [29], Creativity Domain Questionnaire (CDQ) [29] and Critical Thinking Assessment Test (CAT) [28] (Refer Table I). TTCT includes divergent thinking tests where alternative and creative uses of everyday objects or items are asked for and analyzed based on the responses from participants. This is the most widely used and popular instrument for measuring creativity [24]. The CDQ involves a list of self-reported creativity questions where the participants have to rate their own creativity across 56 domains as compared to other individuals with the same expertise in the rated domains [29]. CAT is a critical thinking assessment test developed by Tennessee Tech researchers where there are pre- and post-course self-assessments by students and faculty accessing students' performance on the activities provided based on students' critical and creative thinking skills and behaviors [28].

TABLE I. COMMON INSTRUMENTS USED IN MEASURING CREATIVITY

\begin{tabular}{|l|l|l|}
\hline Reference no. & Countries & Instruments \\
\hline$[21][25]$ & {$[$ USA $][$ New Zealand $]$} & TTCT \\
\hline$[25]$ & {$[$ New Zealand $]$} & CDQ \\
\hline$[24]$ & {$[$ USA $]$} & CAT \\
\hline
\end{tabular}

Several studies have been conducted to measure creativity and to find out how it can be measured and increased in university education systems.

\section{B. Common methods used to teach creativity by CS Educators}

Educators have known the importance of thinking creatively in problem-solving during their courses, thus preparing students for employability. Table II shows the common methods used by CS educators in improving the creativity of their students.

These studies show that the common ways CS educators are using for creativity enhancement in their students are Course lectures [24] [9] [23] [3], Computational Creativity Exercises (CCEs) [25] [18] [19] [20] [21], Game design activities [15] [10] and Brainstorming [10] [4]. Course lectures involve workshops or activities during course lectures. CCEs are group based non-programming active learning activities where students and educators collaboratively work to find solutions. Game design activities involve teaching style involving game designs or robotics experiments. Similarly brainstorming involves generating and evaluating ideas and innovations.
TABLE II. COMMON METHODS USED BY CS EDUCATORS TO TEACH CREATIVITY

\begin{tabular}{|l|l|l|}
\hline Reference no. & Countries & Methods used \\
\hline$[21][8][20][3]$ & $\begin{array}{l}{[\text { USA }][\text { USA }]} \\
{[\text { Uzbekistan }]} \\
{[\text { Finland }]}\end{array}$ & Course Lectures \\
\hline$[25][18][19][20][21]$ & {$[$ USA $]$} & CCE \\
\hline$[15][10]$ & $\begin{array}{l}{[\text { Australia }]} \\
{[\text { Germany }]}\end{array}$ & $\begin{array}{l}\text { Game Design } \\
\text { Activities }\end{array}$ \\
\hline$[10][4]$ & {$[$ Germany $][$ Finland $]$} & Brainstorming \\
\hline
\end{tabular}

These methods used in teaching creativity have been used in many countries (Table II). This shows that importance of creativity is well known to educators. However, there is also a need for articulating creativity as a learning outcome in the courses. Universities might not be purposefully suppressing it, but if they are not actively promoting or emphasizing creativity in the course outlines, students will not have external motivational factors to improve creativity in them while studying the course. Articulating creativity in the course outlines requires giving students a social environment where they can expect creativity and foster their creativity in the course.

\section{FRAMEWORK}

For this research we are following the componential framework of creativity developed by Teresa M. Amabile [2]. This includes the coverage of domain-relevant skills, creativity-relevant skills, and task motivation as the three main components of creative performance.

\section{A. Componential Framework of Creativity}

Componential framework of creativity is a theoretical framework which emphasizes the often-neglected social factors in the creative process. In this framework, cognitive abilities, personality traits and social psychology of creativity are described as equally important factors that promote the different phases of the creative process [2].

\section{Domain-relevant skill}

Domain-relevant skills are applied in particular domain specific cases. Individuals having the required, relevant technical skills, from either formal or informal education in the relevant domain, provide a set of possible responses which are judged by experts also from that domain. This contributes to a cognitive pathway in finding a creative solution to a problem [2].

\section{Creativity-relevant skill}

Creativity-relevant skills relate to the cognitive ability of problem-solving, knowledge, manipulation of information and reasoning ability as a creative performance in generating novel ideas [2].

\section{Task motivation}

Task motivation is one of the important but often ignored components of creative performance which includes the individuals' attitudes towards the task and finding the motivation to perform the task. Task motivation depends on a person's internal motivation towards the task and the presence or absence of external motivational factors such as social environment [2]. 
In this study and from this framework we are focusing on the importance of social environment in task motivation. We are not explaining the domain-relevant skills in detail as everything related to creativity has some domain related. We will be looking into the broad context of course outlines to see for creativity relevant skills mentioned in the outlines. The primary focus is on 'Task Motivation', an important component of creative performance which explains the importance of social environment in promoting creativity in students. In the current situation in universities, it is found that students perform how they are required to, how it has already been done or explained [17]. When we are not including creativity in the course outlines we are not encouraging students to think out of the box and are not promoting the socio-environmental factors in creative implementation.

\section{Motivation}

With the importance of creativity widely reported and researched, universities and teachers might be aware of the advantages of including creativity in their courses for improving the creativity skills of individuals. But are they really implementing it in their learning outcomes? This paper aims to study course outlines of universities across Australia teaching Computer Science in their undergraduate study, look into their Computer Science (CS) curricula and courses to find out the extent to which creativity is articulated as an intended learning outcome. The research outcome will give an overview of the current scenario of CS courses and whether creativity has been given priority as an envisioned learning result.

\section{RESEARCH QUESTION}

In this study the following research question was addressed through analysis of articulated CS curricula and an analysis of intended learning outcomes or learning activities in CS syllabus within Australia.

- How is creativity taught in Australian universities in Computer Science?

\section{METHODOLOGY}

\section{A. Terminology}

Within this study, a "course" refers to a single unit/subject/paper which students complete as part of their university studies. A "program" refers to the overall set of courses that students need to complete to be able to graduate with an undergraduate degree. A three-year CS degree program in Australia typically includes about twenty-four courses.

\section{$B$. How the research question was addressed}

The research question was addressed through analysis of publicly accessible course outlines from accredited CS degree programs throughout Australia. A course outline (sometimes also referred to as "syllabus", "unit outline", or "paper outline") describes the overall structure of a course and primary aims, including the course content and expected assessment tasks which students need to complete to pass the course. Unit outlines are a form of document which can be analyzed to build an understanding of how a topic is addressed in syllabi. For example, over one thousand course outlines from a Canadian tertiary institution were analyzed to understand how creativity was addressed in different disciplines of study. The study showed that the explicit references to creativity in the course outlines were relatively low and infrequent in the data set, only $16 \%$ to be precise [13]. The number varied with disciplines where it was found that creativity is mentioned only $9 \%$ and $1 \%$ in the course outlines of Science and Engineering respectively [13]. Another study analyzed over 1100 course outlines to investigate how creativity was addressed in electrical engineering programs in Australia and New Zealand, finding about two percent of course outlines mentioned creativity [27].

The unit outlines were analyzed qualitatively using the document analysis technique [5]. Document analysis combines aspects of content analysis and thematic analysis and allows a document to be searched either inductively (e.g., finding themes in documents) or deductively (e.g., using keywords).

\section{Scope of Study}

This study was restricted to analysis of undergraduate three-year CS degree programs that were offered by tertiary institutions within Australia in 2020 and were accredited by the Australian Computing Society (under the Seoul accord). Postgraduate courses, and dual/double degrees were not included. In addition, only core/compulsory courses from each degree were analyzed; if creativity is deemed to be important than it should ideally be included as a compulsory part of students' education.

\section{Making a list of unit outlines}

It was necessary to build a list of all the compulsory courses from Australian accredited undergraduate CS programs. To do this, the list of all programs that were accredited by the Australian Computing Society during 2020 was consulted [1]. All bachelor's degrees of three-year duration with "computer science" in the program title were then identified. One issue was that some universities offered multiple degrees with "computer science" in the title (for example due to different accredited majors). So that the results were not biased by any university with several computer science programs (which likely share many courses), only one program was selected from each university for analysis. If the university offered a program with no specific major (e.g., Bachelor of Computer Science), this program was selected. Otherwise, the one at the top of the list was selected, which may be program with a specific major (e.g., Bachelor of Computer Science (Cyber Security)). Overall, nineteen programs from nineteen universities were selected.

Next, the list of compulsory courses within each degree program were identified by accessing the publicly available program handbook from each respective university's website. This was a total of two hundred and eighty-three courses. Compulsory courses per program ranged between seven and twenty-two, depending on the university. Key details for each course were then recorded in a spreadsheet including the course title, course code, year level, and website link for the publicly accessible course outline. 


\section{E. Capturing course outline content}

A Python script was then used to copy key information from the webpage of each publicly accessible course outline to separate text (.txt) files. This created 278 text files, one for each course outline. It was necessary to capture the course outline information for subsequent analysis using NVivo, and because the content of webpages can change at any time (which inhibits analysis if the content changes and also study reproducibility).

\section{F. NVivo Analysis}

NVivo is used in this study for qualitative document analysis. The analysis can be done inductively or deductively. Inductively we would look at the text files and map common themes. For this research we are doing deductive analysis, which means we search for specific keywords and run a query.

The steps involved in the NVivo analysis, after creating the new project, required importing the course outline data files downloaded from university websites into NVivo. In all, 283 files were imported into the project. Out of 283 text files created, the course outlines were available for only 278 courses. It was not possible to gather information for analysis of five courses as no course outlines were available for them. Once the files were imported into the project, text queries were run with our desired keywords.

The text search criteria included search in Files and Externals, Selected Items, Selected Folders or Special Search. Special Search included wildcard, AND, OR, NOT and more. There are other options that NVivo can do, that is, it can look for a keyword along with the variations such as exact match (e.g., "talk"), with stemmed words (e.g., "talking"), with synonyms (e.g., "speak"), with specializations (e.g., "whisper") and with generalizations (e.g., "communicate"). For this study, when searching for the word "creativity", we placed the query in NVivo to find creativity with stemmed words, such as creative or creatively.

Also, under 'Selected Folders' are the lists that are important. For instance, Files, File Classifications, Externals, Nodes, Sentiment, Relationships etc. In this study, we selected 'Files' because we were only looking into those 278 files that were imported. NVivo then searched every single file for the words 'Creativity', 'Innovation' and 'Entrepreneurship' and selected the option to find stemmed words. Similarly, in NVivo, we can also spread our search to Coding Reference, Narrow Context, Broad Context, Custom Context and Entire File. For this research, we spread the search to 'Broad Context'. The reason for this spread is that for the search query result required searching in each file to confirm if it actually mentions searched keywords such as creativity in its course outlines and where they had been mentioned.

The query result showed the list of files in which the search keyword is found, along with the number of references in the file and the percentage covered. This information is summarized in 'Summary' tab. Similarly, there are 'References' and 'Files' tabs in the right-hand side as well. References tab shows where the search term is in the main file and the context where the searched word in used. It is useful to understand in which context the search term is used in the file and to find if it is relevant or not for our study.

\section{RESULTS}

For the document analysis a total of 278 course outlines was studied in broad context. The result shows that out of 278 courses across 19 universities of Australia only 15 courses articulate creativity, innovation, and entrepreneurship in their course outlines. While the professionals of Australia see creativity and innovation as an important skill required in Australia's tertiary education system, these soft skills are not given importance in teaching in CS [6]. We consider creativity as an important soft skill for business success, but we are not implementing it enough in our courses. Considering the term 'creativity' it is found that only $2 \%$ of the courses out of 278 courses, have mentioned creativity in their course outlines, a percentage which is very low. Similarly, the term 'innovation' has been mentioned in only $2.5 \%$ of the course outlines, and 'entrepreneurship' has been mentioned in less than $1 \%$ of the course outlines from total 278 courses. This clearly shows how rarely these terms are mentioned in course outlines though their importance is well known to educators.

TABLE III. INITIAL HITS AND RELEVANT HITS OF THE KEYWORD SEARCHED

\begin{tabular}{|l|c|c|}
\hline Keyword & Initial Hits & Relevant Hits \\
\hline Creativity & 15 & 6 \\
\hline Innovation & 7 & 7 \\
\hline Entrepreneurship & 12 & 2 \\
\hline
\end{tabular}

Table III shows the initial hits resulting from running keyword query searches and actual relevant hits upon the broad context study of the initial courses. Upon running a query for the keywords selected, the result with the number of files and references was provided. For the term 'creativity', 15 files and 15 references resulted from the initial hits. However, with broad context spread and analysis of each files, only 6 of them were found to be relevant ones. For 'innovation' there were 7 files and 7 references and all of them were relevant ones. Finally, the query term 'entrepreneurship' resulted in 12 files and 12 references, out of which the relevant ones were only 2. The reason for showing up in the search result but not being relevant is that search query looked for the term creativity or its stemmed words in the whole course outline text. For example: if the text file contains a list of programs taught such as the Bachelor of Creative Arts, the query will include 'creative arts' as a positive result, however this is not what we were looking for. The relevancy of the file is based on how relevant the file is in terms of creativity, innovation, or entrepreneurship in Computer Science (CS). For finding this relevance, it is important to study each file in broad context. For the broad analysis, each file can be clicked and checked in detail with references, text, and summary.

Table IV shows the course names that have resulted from the query search in the course outlines. Most of the courses appear to be project work or capstone projects which occur during the final years of the undergraduate study. A broad 
analysis on the year in which the listed course was taught can be seen in Table $\mathrm{V}$.

TABLE IV. LIST OF COURSES ARTICULATING KEYWORDS 'CREATIVITY', 'INNOVATION' AND 'ENTREPRENEURSHIP'

\begin{tabular}{|c|c|c|c|}
\hline Keywords & University & Course Name & Course Codes \\
\hline \multirow{6}{*}{ Creativity } & $\begin{array}{l}\text { Murdoch } \\
\text { University }\end{array}$ & Transition to IT & ICT100 \\
\hline & $\begin{array}{c}\text { Charles } \\
\text { Darwin } \\
\text { University }\end{array}$ & $\begin{array}{l}\text { Mobile Web } \\
\text { Structures }\end{array}$ & HIT226 \\
\hline & $\begin{array}{c}\text { Charles } \\
\text { Darwin } \\
\text { University }\end{array}$ & $\begin{array}{l}\text { Building } \\
\text { Interactive } \\
\text { Software }\end{array}$ & HIT237 \\
\hline & $\begin{array}{c}\text { Charles } \\
\text { Darwin } \\
\text { University }\end{array}$ & $\begin{array}{l}\text { Database-Driven } \\
\text { Web } \\
\text { Applications }\end{array}$ & HIT326 \\
\hline & $\begin{array}{l}\text { La Trobe } \\
\text { University }\end{array}$ & $\begin{array}{l}\text { Number Systems } \\
\text { and Linear } \\
\text { Algebra }\end{array}$ & MAT1NLA \\
\hline & $\begin{array}{c}\text { RMIT } \\
\text { University }\end{array}$ & $\begin{array}{l}\text { Algorithms and } \\
\text { Analysis }\end{array}$ & COSC2123 \\
\hline \multirow{7}{*}{ Innovation } & $\begin{array}{c}\text { The } \\
\text { University of } \\
\text { Newcastle }\end{array}$ & $\begin{array}{l}\text { Computer } \\
\text { Science Work } \\
\text { Integrated } \\
\text { Learning Project } \\
\text { Part A }\end{array}$ & COMP3851A \\
\hline & $\begin{array}{c}\text { The } \\
\text { University of } \\
\text { Newcastle }\end{array}$ & $\begin{array}{l}\text { Computer } \\
\text { Science Work } \\
\text { Integrated } \\
\text { Learning Project } \\
\text { Part B }\end{array}$ & COMP3851B \\
\hline & $\begin{array}{c}\text { Deakin } \\
\text { University }\end{array}$ & $\begin{array}{l}\text { Algorithms and } \\
\text { Computing } \\
\text { Systems }\end{array}$ & SIT111 \\
\hline & $\begin{array}{c}\text { Deakin } \\
\text { University }\end{array}$ & $\begin{array}{l}\text { Introduction to } \\
\text { Programming }\end{array}$ & SIT102 \\
\hline & $\begin{array}{l}\text { La Trobe } \\
\text { University }\end{array}$ & $\begin{array}{l}\text { Industry Project } \\
3 \mathrm{~B}\end{array}$ & CSE3PRB \\
\hline & $\begin{array}{c}\text { RMIT } \\
\text { University }\end{array}$ & $\begin{array}{l}\text { Cloud } \\
\text { Computing }\end{array}$ & COSC 2626 \\
\hline & $\begin{array}{l}\text { University of } \\
\text { Wollongong }\end{array}$ & Project & CSIT321 \\
\hline \multirow[t]{2}{*}{ Entrepreneurship } & $\begin{array}{l}\text { Charles Sturt } \\
\text { University }\end{array}$ & $\begin{array}{l}\text { Software } \\
\text { Development } \\
\text { Project } 1\end{array}$ & ITC303 \\
\hline & $\begin{array}{l}\text { La Trobe } \\
\text { University }\end{array}$ & $\begin{array}{l}\text { Industry Project } \\
\text { 3B }\end{array}$ & CSE3PRB \\
\hline
\end{tabular}

Table $\mathrm{V}$ also shows the excerpts from the course outlines that mentioned our searched keywords. The idea of showing the excerpt is to understand how the course outlines are incorporating and promoting creativity, innovation, and entrepreneurship. These course outlines give an idea on what the subject expects from the students and what it provides to the students.

As seen from Table $\mathrm{V}$, the courses offered are more project work courses which are taught in the final year of their study. Project work courses also include writing that a project should be solving some ICT related problem and find some innovative solution creatively. Mentioning these details in course outlines provides an environment of fostering creativity, innovation, and entrepreneurship for the students. The course that teaches students algorithms, computer systems and analysis can help students to be creative with code writing and algorithm analysis which is an important skill for ICT professionals. This document analysis represents the current scenario of CS courses. A more detailed analysis is provided in the discussion section.

TABLE V. COURSE CODES, YEAR LEVELS AND EXCERPTS THAT MENTIONS KEYWORD 'CREATIVITY', 'INNOVATION' AND 'ENTREPRENEURSHIP'

\begin{tabular}{|c|c|c|}
\hline $\begin{array}{l}\text { Course } \\
\text { Codes }\end{array}$ & $\begin{array}{l}\text { Year } \\
\text { Levels }\end{array}$ & Excerpts \\
\hline ICT100 & I & $\begin{array}{l}\text { Helping students to develop skills such as } \\
\text { evaluating information; thinking clearly, } \\
\text { critically, and creatively. }\end{array}$ \\
\hline HIT226 & II & $\begin{array}{l}\text { Demonstrating problem-solving techniques } \\
\text { through creative thinking strategies }\end{array}$ \\
\hline HIT237 & II & $\begin{array}{l}\text { Demonstrating problem-solving techniques } \\
\text { through creative thinking strategies }\end{array}$ \\
\hline HIT326 & III & $\begin{array}{l}\text { Demonstrating problem-solving techniques } \\
\text { through creative thinking to solve client } \\
\text { centered issues. }\end{array}$ \\
\hline MAT1NLA & I & $\begin{array}{l}\text { Explore and creatively apply the ideas and } \\
\text { techniques of mathematics and effectively } \\
\text { communicate the processes and outcomes. }\end{array}$ \\
\hline COSC 2123 & II & $\begin{array}{l}\text { You will gain skills as you apply knowledge } \\
\text { with creativity and initiative to new } \\
\text { situations. }\end{array}$ \\
\hline COMP3851A & III & $\begin{array}{l}\text { Work undertaken in an organization or as an } \\
\text { innovative proposal for an entrepreneurial } \\
\text { prototype }\end{array}$ \\
\hline COMP3851B & III & $\begin{array}{l}\text { Work undertaken in an organization or as an } \\
\text { innovative proposal for an entrepreneurial } \\
\text { prototype }\end{array}$ \\
\hline SIT111 & I & $\begin{array}{l}\text { Major computing system innovations over } \\
\text { the past } 70 \text { years studied, to understand the } \\
\text { role of computer systems and algorithms in } \\
\text { innovation. }\end{array}$ \\
\hline SIT102 & I & $\begin{array}{l}\text { Involves designing and developing new and } \\
\text { innovative software solutions. }\end{array}$ \\
\hline CSE3PRB & III & $\begin{array}{l}\text { Industry project, addresses Innovation and } \\
\text { Entrepreneurship Essential. }\end{array}$ \\
\hline COSC 2626 & III & $\begin{array}{l}\text { Propose innovative solutions to a computing } \\
\text { related problems, teamwork }\end{array}$ \\
\hline CSIT321 & III & $\begin{array}{l}\text { For ICT-based problem students are } \\
\text { required to find innovative and creative } \\
\text { solutions. }\end{array}$ \\
\hline ITC303 & III & $\begin{array}{l}\text { Students applying entrepreneurship skills } \\
\text { during the project planning phase. }\end{array}$ \\
\hline CSE3PRB & III & $\begin{array}{l}\text { This subject addresses Innovation and } \\
\text { Entrepreneurship Essential. }\end{array}$ \\
\hline
\end{tabular}

\section{VIII.DISCUSSION}

From the papers between 1990 to April 12, 2021 (Table I and Table II), that focused on study of creativity in the computer science field, several educators from different countries have included some methods to teach their courses creatively. The aim is to enhance the creativity skill of students, hence improving their employability. However, the document analysis of over thousand courses of Canadian universities suggested that a much lower percentage of the course outlines mentioned creativity in several disciplines of Science and Technology [13]. Also, from the document analysis of 278 courses of 19 universities across Australia, it is found that only $2 \%$ of the courses have covered creativity in their course outlines. It is also possible that educators are using creativity without realizing it. However, if it is not outlined in the course outlines, students will not realize its importance and implementation. Students have the ability to be creative but if they do not realize they are being taught to be creative they will feel the lack of creativity in their educational experience [12]. Hence, it is important to outline 
creativity in the course outlines. The literature study suggests that the importance of creativity, innovation and entrepreneurship is realized in most parts of the world including the fast-growing country, China. Hence, with the realization, several strategies to teach students creatively, thus generating new innovation and flourishing entrepreneurship skill are planned to be included in course teachings. Incorporating it in the course outlines provides motivation and environment to the students to think creatively and improve their problem-solving skills.

A broad analysis of excerpts of the courses from Table $\mathrm{V}$ suggested that some creativity indicators are used in the course outlines. The most used creativity indicators in those courses are problem-solving techniques, thinking creatively, exploring creatively, new ideas, innovations, and entrepreneurship. These indicators, however, do not suggest any creativity increment methods applied by the educators in the courses. They mostly require students to think creatively in their domain-relevant skills rather than setting up a new program, system, or technique for teaching creativity. It is perhaps noteworthy that learning outcomes of various units suggested independent learning. For most of the courses that occur in the first and second year of the study, working independently and in teams to successfully complete a project is suggested. Here, emphasis on teamwork and team motivation seems to be missing. Similarly, working on the ICT-based problems and entrepreneurial prototype projects tends to occur more in the final year of study in the project work or capstone project. These project works involve teamwork, communication with supervisors, ICT professionals, client, users, stakeholders and discussing progress and problems with them. This professional and ethical approach provides task motivation and social environment to the students which helps in nurturing creativity, innovation, and entrepreneurial skills.

This, however, also suggests that only during the final year of the study and during project work, students are provided with the social environment. It suggests that students are not provided with the motivation and environment to be creative in the first and second year of their study. The componential framework of creative process emphasizes the importance of task motivation in enhancing creativity, but if it is introduced only in the later years of study, students will not be able to think creatively only during their final year project. These findings answer our research question on analyzing how creativity is taught in the Australian universities.

A study on an experimental investigation of the innovation capabilities of undergraduate engineering students found out that final year students at a US university provided less innovative solutions to an engineering design problem, than first year students. The ideas of first year students were more original than of their seniors [8]. The findings suggested that the first-year students tend to be more innovative, and innovation is the result of creative and novel thinking. Similarly, this can be the case with CS students. During the first year of the study, students are motivated to learn and explore. When educators fail to provide the required socioenvironmental factor of creativity to the first-year students, they might tend to lose motivation and creative thinking ability in the later years of their study. The consequence of not introducing creativity in the course outlines deprives students from the motivation and social environment of creativity, which ultimately may lead to less innovation and employability. This also impacts on the industry level where graduates from universities will have less creative potential, resulting in a decrease of creative and innovative ideas for problem solving and successful entrepreneurship.

\section{A. Suggestions or Recommendations for CS Educators}

Knowing the importance of creativity for students, CS Educators, course coordinators or the ACS (Australian Computer Society) responsible for preparing course outlines should:

- Provide explicit reference to creativity in the course outlines.

- Describe several creativity enhancing methods in the course outlines that will be followed in the course, for instance brainstorming, team building activities or workshops.

- Highlight how the course has planned to enhance creativity, what can students expect from the course and what is expected from the students in terms of creativity and innovation.

- Make an effort to provide the social environment for students to enhance their creativity level.

- Encourage students for task motivation, teamwork, communication, creative problem-solving and innovation.

\section{B. Possible implications for students}

The absence of creativity in course outlines may also have some implications for students and their creativity.

- Students may not have an environment to articulate creativity explicitly.

- Creativity may not be able to be fostered during the course and task motivation may be reduced.

- Employability factors after graduating may be reduced.

\section{LIMITATIONS}

We do understand the limitations of this study which is only considering course outlines and it cannot measure everything. If this study were not limited to course outlines and could go deeper into the course offerings, the results may be different. However, understanding course offerings and each educator's teaching method is a complex study to undertake.

In addition, this study is carried out on the universities across Australia that offer undergraduate study in CS, however, the findings in Australia may not be generalized with other countries and may be subject to change due to other factors such as cultural, and socio-economic factors. This study only covers the analysis of CS outlines and the study on Software Engineering (SE) and Information Technology (IT) is not included. The inclusion of both SE and IT along with CS might have different results as well. 


\section{CONCLUSION}

Creativity is a $21^{\text {st }}$ century skill which is needed for solving problems and helping students to think creatively during their course study, undergraduate or graduate study, and preparing students for real-work environment situations is the responsibility of educators. The importance of providing students with explicit social environments with task motivation where creativity and innovation can thrive should not be ignored.

This paper provides insights on how creativity is taught in Australian universities and recommendations for educators on planning their course deliverables. The implications on students if creativity is not mentioned in the course outlines have also been studied. Hence, it is important that creativity should be articulated in CS course outlines thus providing students with the social environment to foster creativity.

\section{REFERENCES}

[1] ACS. 2021. Australian Computing Society, "Accredited Courses." ACS. Retrieved June 18, 2021 from https://www.acs.org.au/cpd-education/accredited-courses.html Teresa M. Amabile. 1983. The social psychology of creativity: A componential conceptualization. J. Pers. Soc. Psychol. 45, 2 (1983), 357-376. DOI:https://doi.org/10.1037/00223514.45.2.357

[3] Mikko Apiola, Matti Lattu, and Tomi A. Pasanen. 2010. Students' working strategies and outcomes in a creativitysupporting learning environment. Proc. - Front. Educ. Conf. FIE (2010), 1-7. DOI:https://doi.org/10.1109/FIE.2010.5673344

[4] Mikko Apiola, Matti Lattu, and Tomi A. Pasanen. 2012. Creativity-supporting learning environment-CSLE. ACM Trans. Comput. Educ. 12, 3 (2012), 1-25. DOI:https://doi.org/10.1145/2275597.2275600

Glenn A. Bowen. 2009. Document analysis as a qualitative research method. Qual. Res. J. 9, 2 (2009), 27-40. DOI:https://doi.org/10.3316/QRJ0902027

Commonwealth of Australia. 2017. Inquiry into innovation and creativity: workforce for the new economy-Parliament of Australia. Canberra. Retrieved from http://www.aph.gov.au/Parliamentary_Business/Committees/Hou se/Employment_Education_and_Training/Innovationandcreativit y

[7] DeakinCo. 2017. Soft skills for business success. Deolitte Access Econ. May (2017). Retrieved from

https://www2.deloitte.com/content/dam/Deloitte/au/Documents/E conomics/deloitte-au-economics-deakin-soft-skills-businesssuccess-170517.pdf

[8] Nicole Genco, Katja Holtta-Otto, and Carolyn Conner Seepersad. 2010. An experimental investigation of the innovation capabilities of engineering students. ASEE Annu. Conf. Expo. Conf. Proc. 101, 1 (2010), 60-81. DOI:https://doi.org/10.18260/1-2--16397

[9] Paul Gestwicki and Khuloud Ahmad. 2010. A pilot study on the impact of creative achievement on academic achievement in media-oriented CS1. J. Comput. Sci. Coll. 26, 1 (2010), 85-92. Retrieved from http://dl.acm.org/citation.cfm?id=1858465
Timo Göttel and Jonas Schild. 2011. Creativity room 5555: Evoking creativity in game design amongst CS students. ITiCSE'11 - Proc. 16th Annu. Conf. Innov. Technol. Comput. Sci. (2011), 98-102. DOI:https://doi.org/10.1145/1999747.1999777

[11] Alex Gray. 2016. The 10 skills you need to thrive in the Fourth Industrial Revolution. World Economic Forum. Retrieved November 29, 2020 from https://www.weforum.org/agenda/2016/01/the-10-skills-youneed-to-thrive-in-the-fourth-industrial-revolution/

[12] Kazem Kazerounian and Stephany Foley. 2007. Barriers to creativity in engineering education: A study of instructors and students perceptions. J. Mech. Des. Trans. ASME 129, 7 (2007), 761-768. DOI:https://doi.org/10.1115/1.2739569

[13] Elizabeth Marquis, Kaila Radan, and Alexandra Liu. 2017. A present absence: undergraduate course outlines and the development of student creativity across disciplines. Teach. High. Educ. 22, 2 (2017), 222-238.

DOI:https://doi.org/10.1080/13562517.2016.1237495

[14] Carl J. Neumann. 2007. Fostering creativity. A model for developing a culture of collective creativity in science. $E M B O$ Rep. 8 , 3 (2007), 202-206.

DOI:https://doi.org/10.1038/sj.embor.7400913

[15] Sophie Nichol. 2005. Creative geeks..?: facilitating the creative growth of computer science students using engaging environments. Proc. 17th Aust. Conf. Comput. Interact. Citizens Online Considerations Today Futur. (2005), 1-5.

[16] OECD. 2016. EDUCATION IN CHINA A Snapshot. Retrieved from https://www.oecd.org/education/Education-in-China-asnapshot.pdf

[17] Eleonora Papaleontiou- Louca, Despina Varnava-Marouchou, Simona Mihai, and Elmos Konis. 2014. Teaching for Creativity in Universities. J. Educ. Hum. Dev. 3, 4 (2014). DOI:https://doi.org/10.15640/jehd.v3n4a13

[18] Markeya S. Peteranetz, Abraham E. Flanigan, Duane F. Shell, and Leen Kiat Soh. 2017. Computational Creativity Exercises: An Avenue for Promoting Learning in Computer Science. IEEE Trans. Educ. 60, 4 (2017), 305-313. DOI:https://doi.org/10.1109/TE.2017.2705152

[19] Markeya S. Peteranetz, Abraham E. Flanigan, Duane F. Shell, and Leen Kiat Soh. 2018. Helping Engineering Students Learn in Introductory Computer Science (CS1) Using Computational Creativity Exercises (CCEs). IEEE Trans. Educ. 61, 3 (2018), 195-203. DOI:https://doi.org/10.1109/TE.2018.2804350

[20] Markeya S. Peteranetz, Leen Kiat Soh, and Elizabeth Ingraham. 2019. Building computational creativity in an online course for non-majors. SIGCSE 2019 - Proc. 50th ACM Tech. Symp.

Comput. Sci. Educ. (2019), 442-448. DOI:https://doi.org/10.1145/3287324.3287346

[21] Markeya S. Peteranetz, Shiyuan Wang, Duane F. Shell, Abraham E. Flanigan, and Leen Kiat Soh. 2018. Examining the impact of computational creativity exercises on college computer science students' learning, achievement, self-efficacy, and creativity. SIGCSE 2018 - Proc. 49th ACM Tech. Symp. Comput. Sci. Educ. 2018-Janua, (2018), 155-160. DOI:https://doi.org/10.1145/3159450.3159459

[22] Phillip Phan, Jing Zhou, and Eric Abrahamson. 2010. Creativity, innovation, and entrepreneurship in China. Manag. Organ. Rev. 
6, 2 (2010), 175-194. DOI:https://doi.org/10.1111/j.17408784.2010.00181.x

[23] Shakhnoza Pozilova. 2019. Development of Creativity of Learners in the Courses of Advanced Training and Retraining of Pedagogical Staff in the Process of Studying the Course "Innovative Educational Technology." Int. Conf. Inf. Sci. Commun. Technol. Appl. Trends Oppor. ICISCT 2019 (2019). DOI:https://doi.org/10.1109/ICISCT47635.2019.9011824

[24] Andrea Salgian, Teresa M. Nakra, Christopher Ault, and Yunfeng Wang. 2013. Teaching Creativity in Computer Science. SIGCSE 2013 (2013). DOI:https://doi.org/10.4324/9781410611925

[25] Leen Kiat Soh, Duane F. Shell, Elizabeth Ingraham, Stephen Ramsay, and Brian Moore. 2015. Learning through computational creativity. Commun. ACM 58, 8 (2015), 33-35. DOI:https://doi.org/10.1145/2699391

[26] Anju Thapa, Margaret Hamilton, and Andrew Valentine. 2021. Creativity in Computing Education : A Systematic Review. In 49th Annual Conference of the European Society for Engineering Education (SEFI).

[27] Andrew Valentine, Iouri Belski, Margaret Hamilton, and Scott Adams. 2019. Creativity in Electrical Engineering Degree
Programs: Where Is the Content? IEEE Trans. Educ. 62, 4 (2019), 288-296. DOI:https://doi.org/10.1109/TE.2019.2912834

[28] Anita Vila-Parrish, Susan Carson, Deborah Moore, Maxine Atkinson, Anne Auten, and Sara Queen. 2015. Teaching to foster critical and creativing TH!NKing at North Carolina State University. Proc. 2015 Int. Conf. Interact. Collab. Learn. ICL 2015 September (2015), 1117-1119. DOI:https://doi.org/10.1109/ICL.2015.7318188

[29] Jacqueline Whalley and Harley Ogier. 2020. Paperclips, circles, and six-legged spiders: An exploration of self-perceived and measured creativity among CS students. ACE 2020 - Proc. 22nd Australas. Comput. Educ. Conf. Held conjunction with Australas. Comput. Sci. Week (2020), 11-20.

DOI:https://doi.org/10.1145/3373165.3373167

[30] World Economic Forum. 2020. The Future of Jobs Report 2020 World Economic Forum. Res. Rep. October (2020), 163.

Retrieved from

http://www3.weforum.org/docs/WEF_Future_of_Jobs_2020.pdf 


\section{University Library}

\section{- M M N E R VA A gateway to Melbourne's research publications}

Minerva Access is the Institutional Repository of The University of Melbourne

Author/s:

Thapa, A;Valentine, A;Hamilton, M

Title:

Investigating Creativity in Computer Science Syllabi in Australia

Date:

2021

Citation:

Thapa, A., Valentine, A. \& Hamilton, M. (2021). Investigating Creativity in Computer Science Syllabi in Australia. 2021 IEEE International Conference on Engineering, Technology \& Education, 00, IEEE. https://doi.org/10.1109/TALE52509.2021.9678648.

Persistent Link:

http://hdl.handle.net/11343/294944 